\title{
ВЗАСМОЗВ'ЯЗОК НЕАЛКОГОЛЬНОЇ ЖИРОВОЇ ХВОРОБИ ПЕЧІНКИ 3 КОМПОНЕНТАМИ МЕТАБОЛІЧНОГО СИНДРОМУ У ХВОРИХ НА ІШЕМІЧНУ ХВОРОБУ СЕРЦЯ
}

Запорізький державний медичний університет

Резюме. Неалкогольна жирова хвороба печінки впливає на перебіг серцево-судинних захворювань за рахунок спільних патогенетичних механізмів. 3 метою оцінити взаємозв'язок неалкогольної жирової хвороби печінки 3 компонентами метаболічного синдрому у хворих на ішемічну хворобу серця обстежено 28 осіб. За допомогою стандартних методик проводилося антропометричне дослідження, визначався ліпідний спектр крові, активність АлАТ, АсАТ, показники системи згортання крові. Встановлено, що при ішемічній хворобі серця, поєднаній із неалкогольною жировою

Вступ. Ішемічна хвороба серця (IXC) одна 3 найбільш актуальних проблем сучасної медицини, оскільки посідає перше місце в структурі смертності та інвалідизації населення [5]. Найбільш поширеною формою IXC є стабільна стенокардія напруження. Частота іiі коливається в різних регіонах від 1,8 до 6,5\% [2]. Актуальною проблемою сучасної медицини $€$ виявлення спільних патогенетичних механізмів IXC та супутніх захворювань внутрішніх органів 3 метою розробки комплексного та індивідуального підходу до лікування та профілактики коморбідної патології [16].

На сьогодні поряд із серцево-судинними захворюваннями серйозною медико-соціальною проблемою є гепатобіліарна патологія, оскільки 60 \% хворих із захворюваннями печінки - це особи працездатного віку. Найчастішою формою хронічної патології гепатобіліарного тракту є неалкогольна жирова хвороба печінки (НАЖХП): іiї поширеність у різних популяціях сягає $33 \%$, у тому числі серед хворих на ожиріння - 90 \%, з цукровим діабетом (ЦД) -го типу - 60-70 \%, з метаболічним синдромом (МС) - до $100 \%$ [3, 9, 14].

НАЖХП є самостійною нозологічною формою, що включає наступні стадії: стеатоз печінки, неалкогольний стеатогепатит, фіброз, цироз печінки. Останній, у свою чергу, може призвести до гепатоцелюлярної карциноми. До факторів ризику НАЖХП відносять абдомінальне ожиріння, приналежність до чоловічої статі, інсулінорезистентність, ЦД -го типу та наявність діагностичних ознак метаболічного синдрому [4, 17].

Останнім часом з'являються дані про взаємозв'язок НАЖХП із серцево-судинною патологією, атеросклерозом, дисліпопротеїнемією та метаболічним синдромом [6]. Механізм впливу НАЖХП на кардіоваскулярний ризик до кінця не з'ясований. Припускають, що він пов'язаний із підвищеним надходженням атерогенних прозапальних цитокінів та прокоагулянтних факторів із хворобою печінки, спостерігається більший відсоток хворих з наявністю метаболічного синдрому, що свідчить про тісний зв'язок неалкогольної жирової хвороби печінки з традиційними факторами серцево-судинного ризику. У хворих на ішемічну хворобу серця найбільш суттєвими метаболічними порушеннями, асоційованими 3 неалкогольною жировою хворобою печінки, є гіперглікемія натще, гіпертригліцеридемія та прокоагулянтні зміни крові.

Ключові слова: ішемічна хвороба серця, неалкогольна жирова хвороба печінки, метаболічні порушення.

печінки, ураженої стеатозом [12]. Як основні механізми, які призводять до прогресування як НАЖХП, так і прискоренню атерогенезу, розглядаються також дисліпідемія, інсулінорезистентність, підвищення артеріального тиску, оксидативний стрес, системне запалення, дисбаланс адипокінів, дисфункція ендотелію [15].

Проте залишаються недостатньо з'ясованими клініко-патогенетичні механізми взаємозв'язку НАЖХП із компонентами МС у хворих на IXC.

Мета дослідження. Дослідити взаємозв'язок неалкогольної жирової хвороби печінки з компонентами метаболічного синдрому у хворих на ішемічну хворобу серця.

Матеріал і методи. До поперечного аналітичного дослідження залучили 28 пацієнтів: основну групу склали 15 осіб (середній вік 59,8 2 2,49 року) 3 документально підтвердженої IXC: стабільною стенокардією напруження II-III функціонального класу (ФК) у поєднанні з НАЖХП; групу порівняння - 13 осіб (середній вік 61,11 2 ,22 року) з IXC, але без НАЖХП. Групи зіставлені за віком, статтю, характером супутніх захворювань, тривалістю IXC.

Стенокардію напруження II і III ФК діагностували згідно з класифікацією Канадської асоціації кардіологів. Наявність морфофункціональних ознак неалкогольної жирової хвороби печінки визначали за даними УЗД печінки, тесту Fibromax або пункційної біопсії за необхідністю. Метаболічний синдром діагностовано за критеріями Міжнародної федерації з діабету (International Diabetes Federation, 2005) за принципом «один основний + два додаткових критерії». Наявність та ступінь ожиріння встановлювали на підставі розрахунку індексу маси тіла (IMT) відповідно до критеріїв ВОО3 (1997). Центральний (андроїдний) тип ожиріння визначали за окружністю талії: для чоловіків-європейців $\geq 94$ см; для жінок-європейок $\geq 80$ см (International Dia- 
betes Federation, 2005). Цукровий діабет 2-го типу діагностували відповідно до критеріїв ВОО3 (1999). Діагноз артеріальної гіпертензії встановлювали за рекомендаціями Європейського товариства гіпертензіі, Європейського товариства кардіологів та Української асоціації кардіологів із профілактики та лікування артеріальної гіпертензії (2013).

Критерії включення в дослідження: інформована згода пацієнта, наявність IXC, НАЖХП. Критерії виключення: алкогольна хвороба чи цироз печінки, автоімунні та вірусні гепатити; декомпенсована серцева недостатність; гострий коронарний синдром або гостре порушення мозкового кровообігу менш ніж за три місяці до початку дослідження; природжені або набуті вади серця; системна, онкологічна, автоімунна патологія.

У роботі дотримано принципів біоетики: основних положень Конвенції Ради Свропи про права людини та біомедицину (від 04.04.1997р.), GCP (1996р.), Гельсінської декларації Всесвітньої медичної асоціації про етичні принципи проведення наукових медичних досліджень за участю людини (1964-2000рр.) і наказу МО3 України № 281 від 01.11.2000p. Протокол дослідження схвалений Етичним комітетом Запорізького державного медичного університету. До включення в дослідження всі учасники надали письмову інформовану згоду.

Усім хворим на IXC при надходженні до стаціонару проводили комплексне обстеження згідно із загальноприйнятими стандартами (наказ MO3 України № 436 від 03.07.2006). Для вирішення завдань дослідження використовували наступні методи: клінічні - збір скарг та анамнезу, фізикальне обстеження - для оцінки суб'єктивних та об'єктивних проявів захворювання; антропометричне вимірювання - зріст, маса тіла, індекс маси тіла (IMT), окружність талії (ОT), окружності стегон (ОС), коефіцієнт централізації жиру - співвідношення окружність талії до окружності стегон. Розрахунок IMT проводився за формулою: IMT = маса тіла (кг) / зріст $\left(\mathrm{м}^{2}\right)$. Визначення рівня загального холестерину (ЗХC), тригліцеридів (ТГ), холестерину ліпопротеїдів високої щільності (ХС ЛПВЩ) проводили з вико- ристанням набору реактивів Biolatest компанії PLIVA-LACHEMA (Чеська Республіка) за допомогою автоматичного біохімічного фотометрааналізатора. Рівень холестерину ліпопротеїдів низької щільності (ХС ЛПНЩ) розраховували за формулою Friedewald (1972): ХС ЛПНЩ = ЗХС (ХС ЛПВЩ + ТГ/2,2). Для розрахунку індексу атерогенності (IA) використовували наступну формулу: $\mathrm{IA}=$ (ЗХC-XC ЛПВЩ) / ХC ЛПВЩ. Рівень глюкози крові, активність аланінамінотрансферази (АлАТ), аспартатамінотрансферази (АсAТ), показники тимолової проби, концентрацію загального білірубіну досліджували за загальноприйнятими методиками. Концентрацію фібриногену визначали гравіметричним методом Рутберга Р.А. (1961). Протромбіновий індекс (ПТІ) визначали згідно 3 методом Туголукова В.И. (1952).

Статистичну обробку даних проводили 3 використанням пакетів програм «STATISTICA $®$ for Windows $10.0 »$ (StatSoft Inc.). Дані представлені у вигляді медіани і міжквартильного розмаху - Me (Q25-Q75) при описі кількісних ознак, якісних - у відсотках. Для порівняння показників у двох незалежних групах використовували Uкритерій Манна-Уітні. Порівняння якісних показників проводили за допомогою критерію Фішера та $\chi 2$. Для оцінки взаємозв'язку між ознаками використовували кореляційний аналіз із розрахунком коефіцієнта рангової кореляції Спірмена (r). Статистично значущими відмінності вважали при $\mathrm{p}<0,05$.

Результати дослідження та їх обговорення. Клініко-анамнестична характеристика хворих на IXC зі стабільною стенокардією залежно від наявності НАЖХП наведена в таблиці 1.

Аналіз частоти зустрічальності традиційних факторів ризику CC3 у хворих на IXC, поєднану з НАЖХП показав, що серед пацієнтів основної групи на 50 \% більше осіб страждають абдомінальним ожирінням $\left(\chi^{2}=7,479 ; \mathrm{df}=1 ; \mathrm{p}<0,01\right)$ та на $43,59 \%$ більше хворих, що мають дисліпідемію $\left(\chi^{2}=5,32 ; \mathrm{df}=1 ; \mathrm{p}<0,05\right)$. Достовірності між двома групами за частотою зустрічальності АГ $(\chi 2=1,152 ; \mathrm{df}=1 ; \mathrm{p}>0,05)$ та ЦД 2 типу $(\chi 2=1,197$; $\mathrm{df}=1 ; \mathrm{p}>0,05)$ не виявлено. Отримані результати підтверджують дані про те, що поширеність

Таблиця 1

Клініко-анамнестична характеристика хворих на ішемічну хворобу серця зі стабільною стенокардією залежно від наявності неалкогольної жирової хвороби печінки (абс./\%)

\begin{tabular}{|c|c|c|}
\hline Показник & $\begin{array}{c}\text { IXC } \\
(\mathrm{n}=13)\end{array}$ & IХС та НАЖХП (n=15) \\
\hline Артеріальна гіпертензія & $7(53,8 \%)$ & $11(73,3 \%)$ \\
\hline ЦД 2-го типу & $2(15,38 \%)$ & $5(33,33 \%)$ \\
\hline Ожиріння І-ІІІ ступеня & $2(15,38 \%)$ & $10(66,66 \%)^{*}$ \\
\hline Надлишкова вага & $1(7,69 \%)$ & $4(26,66 \%)$ \\
\hline Дисліпідемія & $3(23,07 \%)$ & $10(66,66 \%)^{*}$ \\
\hline
\end{tabular}

Примітка. * - вірогідність різниці показників між групами хворих на ішемічну хворобу серця 3 неалкогольною жировою хворобою печінки та без супутньої патології печінки $(\mathrm{p}<0,05)$ 
Таблиця 2

Клінічно-лабораторні параметри у хворих на ішемічну хворобу серця зі стабільною стенокардісю залежно від наявності неалкогольної жирової хвороби печінки

\begin{tabular}{|c|c|c|}
\hline Показник, одиниці виміру & IXС $(\mathrm{n}=13)$ & IХC та НАЖХП $(\mathrm{n}=15)$ \\
\hline АТ сит. & $130,0(120,0 ; 135,0)$ & $160,0(160,0 ; 170,0)$ \\
\hline АТ діаст. & $80,0(65,0 ; 90,0)$ & $95,0(90,0 ; 100,0)$ \\
\hline ІМТ, кг/м & $31,24(28,73 ; 37,62)^{*}$ \\
\hline ОТ, см & $28,73(27,7 ; 31,88)$ & $94,82(88,5 ; 105,1)^{*}$ \\
\hline ЗХС, ммоль/л & $89,13(79,3 ; 101,6)$ & $5,67(4,24 ; 6,29)$ \\
\hline ЛПНЩ, ммоль/л & $4,84(4,57 ; 6,32)$ & $2,86(2,14 ; 4,29)$ \\
\hline ЛПВЩ, ммоль/л & $3,91(3,35 ; 4,1)$ & $1,11(0,75 ; 1,37)$ \\
\hline ТГ, ммоль/л & $1,2(1,12 ; 1,48)$ & $2,27(1,28 ; 2,75)^{*}$ \\
\hline ІА & $1,66(0,8 ; 1,95)$ & $3,63(3,42 ; 3,81)$ \\
\hline Глюкоза крові, ммоль/л & $3,03(2,13 ; 3,76)$ & $5,0(4,2 ; 5,6)$ \\
\hline АЛТ, мкмоль/ч×мл & $4,35(4,1 ; 4,9)$ & $0,61(0,51 ; 0,79)$ \\
\hline АСТ, мкмоль/ч×мл & $0,55(0,34 ; 0,68)$ & $0,49(0,33 ; 0,72)$ \\
\hline Білірубін, мкмоль/л & $0,44(0,38 ; 0,58)$ & $14,45(8,75 ; 18,0)$ \\
\hline Тимолова проба, ОД & $14,35(10,0 ; 17,3)$ & $2,33(1,61 ; 3,0)$ \\
\hline ПТІ, \% & $3,02(2,0 ; 3,86)$ & $99,5(6,84 ; 109,5)^{*}$ \\
\hline Фібриноген, г/л & $86,0(10,5 ; 95,0)$ & $2,71(1,35 ; 3,94)$ \\
\hline
\end{tabular}

Примітка. * - вірогідність різниці показників між групами хворих на ішемічну хворобу серця з неалкогольною жировою хворобою печінки та без супутньої патології печінки $(\mathrm{p}<0,05)$

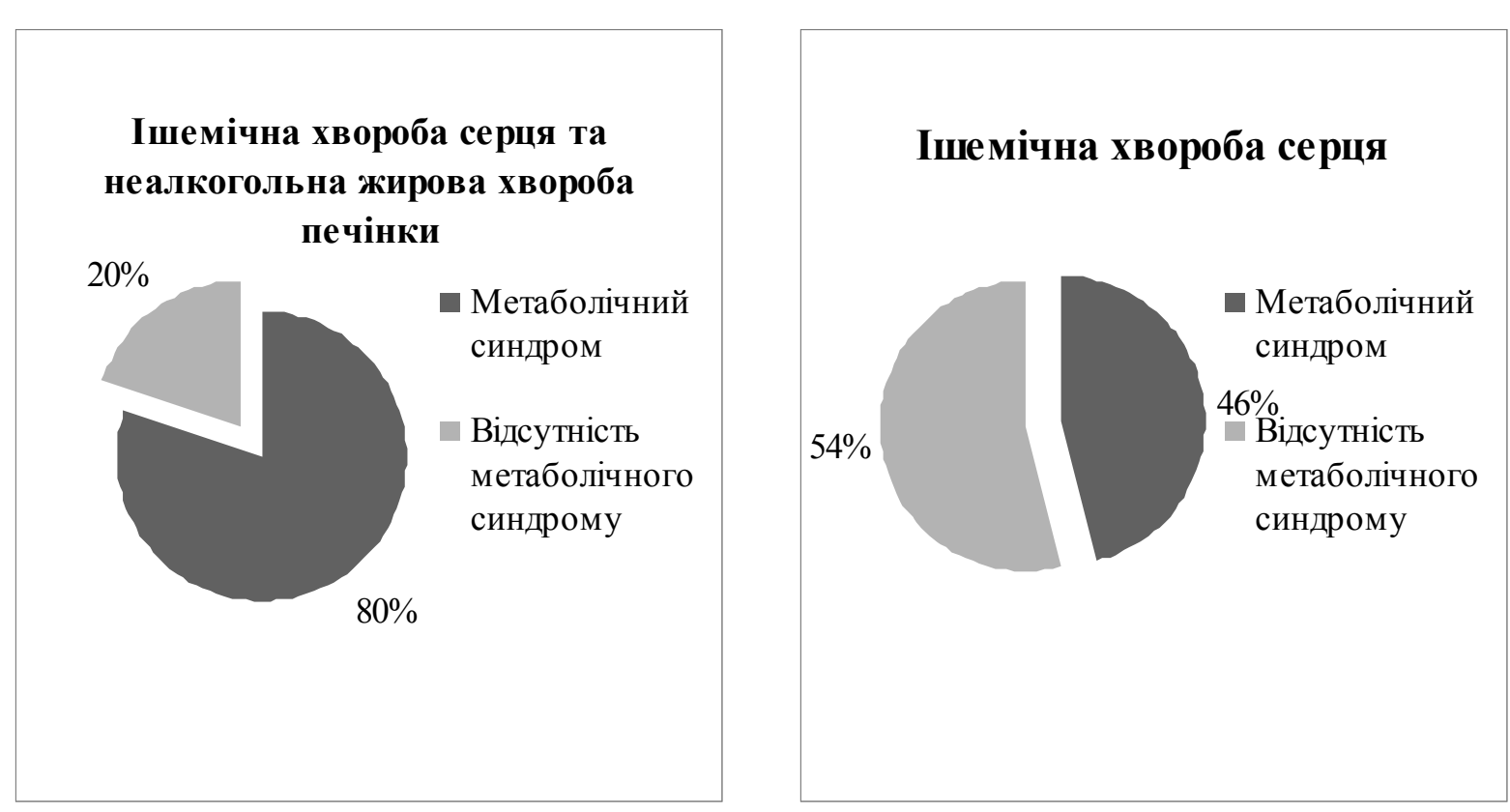

Рис. 1. Розподіл хворих за наявністю метаболічного синдрому

НАЖХП зростає зі збільшенням маси тіла та високий ступінь ожиріння збільшує ризик ії розвитку [8].

У групі хворих на IXC та НАЖХП переважає кількість пацієнтів, що мали три та чотири складові метаболічного синдрому, тоді як у групі порівняння переважна більшість осіб була без ознак метаболічного синдрому (рис. 1). Отримані дані збігаються із сучасними науковими дослідженнями, згідно з якими НАЖХП є складним захворюванням, що може призводити до прогресування IXC і розвитку негативних кардіоваскулярних подій внаслідок метаболічних порушень $[7,13]$.

Особливості клінічно-лабораторних даних у хворих на IXC зі стабільною стенокардією залеж- 
но від наявності НАЖХП наведено в таблиці 2. У пацієнтів обстежених груп виявлені статистично значущі відмінності в антропометричних показниках. Так, IMT та ОТ у хворих на IXC, коморбідну з НАЖХП, були достовірно вище, ніж у пацієнтів групи порівняння (на 8,73 \% та 6,38 \% відповідно; $\mathbf{p}<0,05)$.

Рівень тригліцеридів також значимо вище на 36,7 \% в основній групі порівняно 3 пацієнтами без НАЖХП ( $<<0,05)$. При цьому рівень $3 Х С$ суттєво між групами не відрізнявся. У пацієнтів основної групи спостерігалась тенденція до збільшення ЛПНП, індексу атерогенності та зменшення рівня ЛПВЩ. Тенденційне збільшення рівня глюкози в пацієнтів основної групи може бути зумовлено більшим відсотком хворих на ЦД 2-го типу.

При вивченні функціонального стану печінки встановлено, що показники активності АлАТ та АcАТ у пацієнтів на IXC, поєднану з НАЖХП, порівняно з особами без НАЖХП, не відрізнялися. При цьому рівень АлАТ мав тенденцію до перевищення над рівнем АсАТ хворих на НАЖХП. За рівнями білірубіну та тимолової проби різниця між обстежуваними групами не була достовірною. Це пояснюється тим, що більша кількість хворих на НАЖХП мала стеатогепатоз $(66,66 \%)$, а не стеатогепатит $(33,33 \%)$.

При аналізі показників коагуляційного гемостазу виявлено тенденцію до підвищення вмісту в сироватці крові рівня фібриногену в пацієнтів із поєднаним перебігом IXC та НАЖХП порівняно 3 групою контролю. У пацієнтів основної групи був достовірно вищий ПТІ на $15 \%(\mathrm{p}<0,05)$, що може свідчити про наявність гіперкоагуляційного синдрому в даної категорії хворих як чинника прогресування IXC [11].

Таким чином, у пацієнтів основної групи вірогідно вище IMT, ОT, частіше спостерігалося підвищення рівня тригліцеридів та протромбінового індексу. Ці зміни вказують на більш виражені порушення ліпідного спектра крові, а також протромботичні зміни крові у хворих на IXC зі стабільною стенокардією, поєднану з НАЖХП.

Для оцінки взаємозв'язку між функціональним станом печінки та компонентами метаболічного синдрому у хворих на IXC, коморбідну 3 НАЖХП, проведений кореляційний аналіз. Виявлені зв'язки між АсAT та IMT (r=+0,59; $<<0,05)$, ПТІ $(\mathrm{r}=+0,78 ; \mathrm{p}<0,05)$, індексом атерогенності $(\mathrm{r}=+0,78 ; \mathrm{p}<0,05), \quad$ глюкозою крові $(\mathrm{r}=+0,69$; $\mathrm{p}<0,05)$.

Підвищення IMT у пацієнтів із поєднаним перебігом IXC та НАЖХП узгоджується з даними літератури про велику питому вагу неалкогольного стеатозу печінки в пацієнтів із надмірною масою тіла. За даними А. Galassi (2006), J.B. Dixon (2001) від 70 до $100 \%$ пацієнтів із НАЖХП страждають на ожиріння [20]. За даними L.M. Alba, K. Lindor (2003) ожиріння II та III ступеня в 95-100 \% випадках поєднуються з розвитком жирової дистрофії печінки [18]. За результатами дослідження А.О. Буєверова та співавт. (2005), ожиріння в $95 \%$ асоціюється з розвитком стеатозу, а у 20-47 \% - 3 неалкогольним стеатогепатитом [1].

У ряді досліджень показано, що серед ліпідних порушень НАЖХП частіше асоціюється 3 гіпертригліцеридемією, яку, згідно із сучасними даними, розглядають як важливий незалежний фактор ризику IXC [10]. H. Knobler (2006) при обстеженні 48 хворих на НАЖХП виявив гіпертригліцеридемію в 73 \% випадків [19]. Автор пояснює це тим, що при втраті жировою тканиною чутливості до інсуліну в крові збільшується рівень ТГ і вільних жирних кислот. Формується замкнуте коло, в якому ожиріння, стеатоз печінки та інсулінорезистентність $є$ пов'язаними факторами, що стимулюють взаємне прогресування.

\section{Висновки}

1. При ішемічній хворобі серця, поєднаній 3 неалкогольною жировою хворобою печінки, спостерігається більший відсоток хворих з наявністю метаболічного синдрому, що свідчить про тісний зв'язок неалкогольної жирової хвороби печінки із традиційними факторами серцевосудинного ризику.

2. У хворих на ішемічну хворобу серця, коморбідну 3 неалкогольною жировою хворобою печінки, встановлені вірогідні кореляційні взаємозв'язки функціонального стану печінки з показниками вуглеводного та ліпідного обмінів, антропометричними параметрами, протромботичними змінами крові.

Перспективи подальших досліджень. Пошук предикторів несприятливого перебігу ішемічної хвороби серця, асоційованої з неалкогольною жировою хворобою печінки, та розробка критеріїв підбору оптимальних схем діагностики та лікування цієї категорії хворих $є$ важливим напрямком наступних наукових досліджень.

\section{Література}

1. Буеверов А.О. Многофакторный генез жировой болезни печени / А.О. Буеверов, П.О. Богомолов // Гепатол. форум. - 2006. - С. 6-12.

2. Горбась І.М. Ішемічна хвороба серця: епідеміологія і статистика / І.М. Горбась // Здоров’я України. - 2009. - № 3. - C. 34-35.

3. Драпкина О.М. Неалкогольная жировая болезнь печени и сердечно-сосудистый риск: влияние женского пола / О.М. Драпкина, О.Н. Корнеева // Фарматека. 2010. - № 15. - С. 28-33.

4. Звягинцева Т.Д. Хронические диффузные заболевания печени сочетанной этиологии: подходы к лечению с позиций доказательной медицины / Т.Д.Звягинцева, А.И. Чернобай // Здоров'я України. - 2011. - № 11-12. - С. 50-51.

5. Коваленко В.М. Стрес і хвороби системи кровообігу / В.М. Коваленко, В.М. Корнацький. - К., 2015. - 355 с.

6. Колесникова Е.В. Неалкогольная жировая болезнь печени и артериальная гипертензия: чего мы достигли в понимании проблемы / Е.В. Колесникова // Укр. мед. часопис. - 2014. - № 3. - С. 61-66.

7. Колесникова Е.В. Современный пациент с заболеванием печени и патологией сердечно-сосудистой системы: какой выбор сделать? / Е.В. Колесникова // Сучас. гастроентерол. - 2014. - № 2 (76). - С. 82-94. 
8. Курята А.В. Функциональное состояние эндотелия сосудов у пациентов с ишемической болезнью сердца в сочетании с неалкогольной жировой болезнью печени в зависимости от массы тела и влияния статинотерапии / А.В. Курята, М. М. Гречаник // Запорож. мед. ж. - 2015. - № 1 (88), - С. 14-19.

9. Малышев П.П. Неалкогольная жировая болезнь печени: аспекты диагностики и лечения / П.П Малышев, К.В. Иванова // Consilium Medicum. Гастроэнтерол. 2010. - № 2. - С. 30-37.

10. Михальчук Л.М. Неалкогольна жирова хвороба печінки / Л.М. Михальчук, А.С. Єфімов // Междунар. эндокринол. ж. - 2010. - № 2 (26). - С. 71-82.

11. Морозов Ю.А. Нарушения системы гемостаза при патологии печени и их диагностика / Ю.А. Морозов, Р.В. Медников, М.А. Чарная // Геморрагические диатезы, тромбозы, тромбофилии. - 2014. - № 1. - С. 162-174.

12. Ожиріння й неалкогольна жирова хвороба печінки 3 позиції кардіоваскулярного ризику в практиці сімейного лікаря / В.І. Величко, Л.І. Колотвіна, А.М. Гур'єв [та ін.] // Мед. транспорту України. - 2014. - № 1. C. $79-82$.

13. Особливості молекулярних механізмів розвитку неалкогольної жирової хвороби печінки / А.А. Чумак, Л.М. Овсяннікова, А.В. Кубашко [та ін.] // Укр. мед. часопис. - 2013. - № 6 (98). - С. 33-40.

14. Панькив В.И. Сахарный диабет 2-го типа и неалкогольная жировая болезнь печени. Эффекты метформи- на / В.И. Панькив // Междунар. эндокринол. ж. - 2013. - № 5 (53). - С. 55-63.

15. Ранние признаки атеросклероза у больных с неалкогольной жировой болезнью печени / Г.Д. Фадеенко, Т.А. Соломенцева, И.Э. Довганюк [та ін.] // Сучас. гастроентерол. - 2014. - № 4 (78). - С. 32-37.

16. Фадєєнко Г.Д. Коморбідна патологія, що впливає на серцево-судинний ризик у постінфарктних хворих / Г.Д. Фадєєнко, В.А. Чернишов // Укр. терапевт. ж. 2014. - № 2. - С. 11-20.

17. Хухліна О.С. Неалкогольна жирова хвороба печінки: етіологія, епідеміологія, особливості перебігу, діагностика, прогноз / О.С. Хухліна // Укр. мед. часопис. 2006. - № 1 (51). - C. 89-95.

18. Alba L.M. Review article: Non-alcoholic fatty liver disease / L.M. Alba, K. Lindor // Alimentary Pharmacology \& Therapeutics. - 2003. - Vol. 18 (8). - P. 977-986.

19. Cardiac abnormalities as a new manifestation of nonalcoholic fatty liver disease: echocardiographic and tissue Doppler imaging assessment / H. Knobler, S. Goland, S. Shimoni [et al.] // J. of Clin. Gastroenterology. - 2006. - Vol. 40. - P. 949-955.

20. Galassi A. Metabolic syndrome and risk of cardiovascular disease: a meta-analysis / A. Galassi, K. Reynolds, J. He // Am. J. of Medicine. - 2006. - Vol. 119 (10). - P. 812-819.

\section{ВЗАИМОСВЯЗЬ НЕАЛКОГОЛЬНОЙ ЖИРОВОЙ БОЛЕЗНИ ПЕЧЕНИ С КОМПОНЕНТАМИ МЕТАБОЛИЧЕСКОГО СИНДРОМА У БОЛЬНЫХ ИШЕМИЧЕСКОЙ БОЛЕЗНЬЮ СЕРДЦА}

\section{Н.С. Михайловская, Л.Е. Миняйленко}

Резюме. Неалкогольная жировая болезнь печени влияет на течение сердечно-сосудистых заболеваний за счет общих патогенетических механизмов. С целью оценить взаимосвязь неалкогольной жировой болезни печени с компонентами метаболического синдрома у больных ишемической болезнью сердца обследовано 28 больных. С помощью стандартных методик проводилось антропометрическое исследование, определялся липидный спектр крови, активность АлАТ, АсАТ, показатели системы свертывания крови. При ишемической болезни сердца, сочетанной с неалкогольной жировой болезнью печени, регистрировался больший процент больных с наличием метаболического синдрома, что свидетельствует о тесной связи неалкогольной жировой болезни печени с традиционными факторами сердечно-сосудистого риска. У больных ишемической болезнью сердца наиболее существенными метаболическими нарушениями, ассоциированными с неалкогольной жировой болезнью печени, являются гипергликемия натощак, гипертриглицеридемия и прокоагулянтные изменения крови.

Ключевые слова: ишемическая болезнь сердца, неалкогольная жировая болезнь печени, метаболические нарушения.

\section{RELATIONSHIP OF NONALCOHOLIC FATTY LIVER DISEASE WITH COMPONENTS OF METABOLIC SYNDROME IN PATIENTS WITH ISCHEMIC HEART DISEASE}

\section{N.S. Mykhailovska, L.E. Miniailenko}

Abstract. Nonalcoholic fatty liver disease affects the progression of cardiovascular diseases by common pathogenic mechanisms. To evaluate the relationship of nonalcoholic fatty liver disease with components of metabolic syndrome in patients with coronary heart disease we examined 28 patients. Using standard techniques we conducted anthropometric measurements, determined blood lipid profile, the activity of ALT, AST and indicators of blood coagulation. In ischemic heart disease combined with nonalcoholic fatty liver disease, it was recorded a higher percentage of patients with the presence of metabolic syndrome, indicating a close relationship of nonalcoholic fatty liver disease with traditional factors of cardiovascular risk. In patients with coronary heart disease the most serious metabolic disorders, associated with nonalcoholic fatty liver disease is fasting hyperglycemia, hypertriglyceridemia and pro-coagulating blood changes.

Key words: coronary heart disease, nonalcoholic fatty liver disease, metabolic disorders.

State Medical University (Zaporizhzhia)

Рецензент - проф. С.В. Білецький
Buk. Med. Herald. - 2016. - Vol. 20, № 1 (77). - P. 79-83

Надійшла до редакції 29.11.2015 року

() Н.С. Михайловська, Л.С. Міняйленко, 2016 